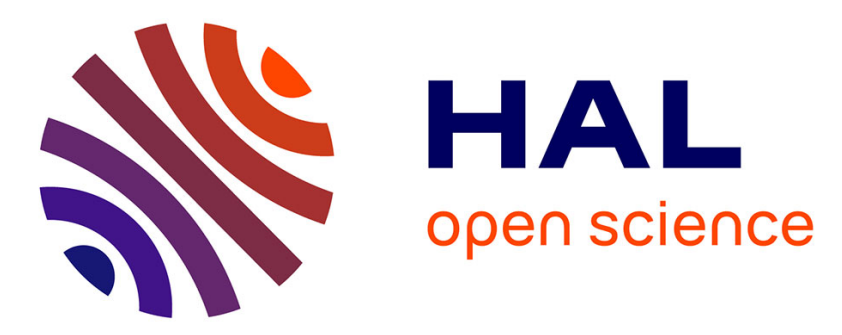

\title{
Alloys to Replace Mg Anodes in Efficient and Practical Mg-Ion/Sulfur Batteries
}

Zhen Meng, Dominique Foix, Nicolas Brun, Rémi Dedryvère, Lorenzo

Stievano, Mathieu Morcrette, Romain Berthelot

\section{- To cite this version:}

Zhen Meng, Dominique Foix, Nicolas Brun, Rémi Dedryvère, Lorenzo Stievano, et al.. Alloys to Replace Mg Anodes in Efficient and Practical Mg-Ion/Sulfur Batteries. ACS Energy Letters, 2019, pp.2040-2044. 10.1021/acsenergylett.9b01389 . hal-02268144

\section{HAL Id: hal-02268144 \\ https://hal.science/hal-02268144}

Submitted on 29 Oct 2021

HAL is a multi-disciplinary open access archive for the deposit and dissemination of scientific research documents, whether they are published or not. The documents may come from teaching and research institutions in France or abroad, or from public or private research centers.
L'archive ouverte pluridisciplinaire HAL, est destinée au dépôt et à la diffusion de documents scientifiques de niveau recherche, publiés ou non, émanant des établissements d'enseignement et de recherche français ou étrangers, des laboratoires publics ou privés. 


\section{Alloys to Replace $\mathrm{Mg}$ Anodes in Efficient and Practical Mg-ion/Sulfur Batteries}

Zhen Meng, ${ }^{1,4}$ Dominique Foix, ${ }^{2,4}$ Nicolas Brun, ${ }^{1}$ Rémi Dedryvère, ${ }^{2,4}$ Lorenzo

Stievano, ${ }^{1,4}$ Mathieu Morcrette, ${ }^{3,4}$ Romain Berthelot ${ }^{1,4 *}$

1: ICGM, UMR 5253 CNRS, Univ. Montpellier, 34095Montpellier, France

2: IPREM - UMR 5254 CNRS, Université de Pau et des Pays de l'Adour, Hélioparc, 2 Avenue Pierre Angot, 64053 Pau Cedex 9, France

3: Laboratoire de Réactivité et Chimie des Solides (LRCS), UMR 7314 CNRS, Université de Picardie Jules Verne, HUB de l'Energie, 15 rue Baudelocque, 80039, Amiens, France

4: RS2E, FR 3459 CNRS, HUB de l'Energie, 15 rue Baudelocque, 80039, Amiens, France

\section{Corresponding Author}

* Dr. Romain Berthelot

Institut Charles Gerhardt de Montpellier - Université de Montpellier, CC1502

2, place Eugène Bataillon - 34095 Montpellier - France 


\begin{abstract}
The development of rechargeable $\mathrm{Mg} / \mathrm{S}$ battery is driven by the design of reliable electrolytes. So far, they seem not suitable for industrial transfer as they are either corrosive or necessitate a complex formulation. The innovative strategy reported here which replaces magnesium by $\mathrm{Mg}$ alloys at the negative electrode enables employing facile electrolyte formulations as well as proposing an easier shaping process of the electrode. As proof-of-concept, $\mathrm{Mg}_{3} \mathrm{Bi}_{2} / \mathrm{S}$ cells were evaluated with simple $\mathrm{Mg}(\mathrm{TFSI})_{2} / \mathrm{DME}$ electrolyte. Electrochemical mechanisms including $\mathrm{Mg}_{3} \mathrm{Bi}_{2}$ de-alloying and sulfur magnesiation was probed by XRD and XPS, respectively. On top of that, very promising cycling performance at elevated current density is obtained. This preliminary findings pave the way for further improvements towards further practical applications.
\end{abstract}

\title{
TOC GRAPHICS
}

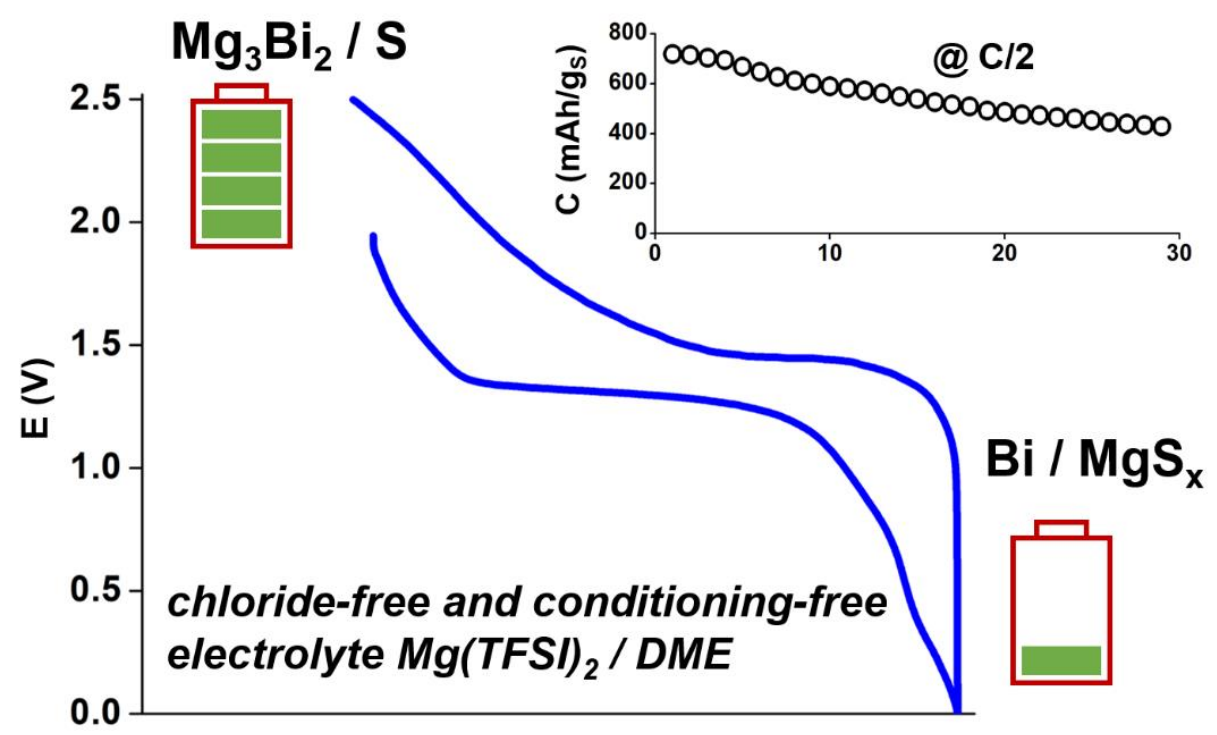


A smart and more efficient energy management is required for drawing a better world. This encompasses greener ways to produce energy, and more coherent and eco-friendly systems to store and transport it. A revolutionary innovation has been the incorporation of electrochemical energy storage in the form of batteries into our energy life cycle. Among the different storage systems, the lithium-ion technology has revolutionized portable electronics and is making long-range electric vehicles a reality. However, after continuous improvements over the last decades, Li-ion batteries are approaching their limits in terms of energy density and cost. Moreover, the everincreasing need of batteries might face limited resources (for lithium and more likely cobalt or nickel), generating cost rise and geopolitical tensions. It is therefore important to look at alternative systems combining sustainability and satisfactory storage performance. In this context, $\mathrm{Mg}$ batteries have received a considerable attention in the past two decades since the first rechargeable prototype reported by Aurbach. ${ }^{1}$ Indeed, the use of $\mathrm{Mg}$ theoretically offers high volumetric capacity (3.8 Ah/ $\mathrm{cm}^{3}$ compare to $2.1 \mathrm{Ah} / \mathrm{cm}^{3}$ for $\mathrm{Li}$ ) and the combination with its relatively low standard reduction potential ( $2.4 \mathrm{~V} v$ s. NHE) enables considering high volumetric energy density systems. However, the sluggish diffusion of $\mathrm{Mg}^{2+}$ ions into typical electrode hosts such as layered or polyanionic compounds is a major hurdle toward the development of practical and high performance Mg batteries. ${ }^{2-5}$ Shifting from insertion to conversion electrochemical process, using sulfur-based electrodes is now a widely established way to access high capacities at the positive side as well. ${ }^{6}$ In theory, a $\mathrm{Mg} / \mathrm{S}$ cell could deliver high specific gravimetric and volumetric energy densities of $1300-1700 \mathrm{Wh} / \mathrm{kg}$ and $2500-3200 \mathrm{Wh} / \mathrm{L}$, respectively. Moreover, combining magnesium and sulfur in the same rechargeable batteries seems very attractive nowadays, when sustainability becomes as important as performance.

The design of the electrolyte is driven and constrained by the peculiar chemical and electrochemical features of magnesium and sulfur. The electrolyte needs to be non-nucleophilic and must prevent the passivation of the Mg surface, which could hinder any electrochemical plating/stripping process. In 2011, the research group of Toyota reported the first example of rechargeable $\mathrm{Mg} / \mathrm{S}$ battery using an electrolyte containing an electrochemical active complex created in situ from $\mathrm{HMDSMgCl}$ and $\mathrm{AlCl}_{3}$ salts. ${ }^{7}$ After that, the use of bisamides salt $\operatorname{Mg}(\mathrm{HMDS})_{2}$ has been generalized by Fichtner and Zhao-Karger, ${ }^{8-12}$ while working with $\operatorname{Mg}(\mathrm{TFSI})_{2}$ salt has been more and more considered (Table S1). However, in both cases the mandatory presence of chloride additives $\left(\mathrm{AlCl}_{3}, \mathrm{MgCl}_{2}\right)$ increases the corrosive nature of the 
electrolyte and compel the use of noble metal current collectors that are not suitable for practical large-scale production. When chloride-free formulations are evaluated, a preliminary conditioning treatment based on successive voltammetry sweeps appears necessary but barely suitable for practical applications. ${ }^{13,14}$ Indeed, the electrochemically cleaned volume is limited, and the readyto-use electrolyte should be transferred from the electrochemical cell to the $\mathrm{Mg} / \mathrm{S}$ cell. In 2017, Zhao-Karger et al. reported a new class of non-corrosive and efficient electrolytes using fluorinated alkoxyborate magnesium salt $\operatorname{Mg}\left[\mathrm{B}(\mathrm{HFIP})_{4}\right]_{2} ;{ }^{15,16}$ however the synthesis of the latter is complex and still far from industrial transfer.

The novel concept introduced with this Letter is the replacement of the Mg anode by an alloy containing magnesium allowing the use of simple, non-corrosive electrolytes with a preparation that is suitable for future practical application. The concept lies on the ability of some $p$-block elements (e.g., $\mathrm{In}, \mathrm{Sn}, \mathrm{Sb}, \mathrm{Pb}$ and $\mathrm{Bi}$ ) to reversibly electrochemically alloy with magnesium. ${ }^{17-20}$ The electrochemical formation of $\mathrm{MgIn}, \mathrm{Mg}_{2} \mathrm{Sn}, \mathrm{Mg}_{3} \mathrm{Sb}_{2}, \mathrm{Mg}_{3} \mathrm{Bi}_{2}$ and $\mathrm{Mg}_{2} \mathrm{~Pb}$ occurs during a relatively flat biphasic plateau at low voltage and corresponds to high capacities (Table S2). The significant volume changes induced by successive alloying/de-alloying processes has been thought for long time as an important drawback. However, thanks to an appropriate electrode formulation, long-time cycling with high capacity retention could be achieved. ${ }^{21,22}$ Considering that these alloys are more compatible with conventional electrolyte formulations than $\mathrm{Mg}$ metal, they represent topranking negative electrode materials for rechargeable Mg-ion batteries. The direct use of alloys enables one to investigate $\mathrm{Mg}$-free positive electrode materials. Very recently $\mathrm{Mg}_{2} \mathrm{Sn}$ and $\mathrm{Mg}_{3} \mathrm{Bi}_{2}$ were implemented in full cells to evaluate vanadium oxide, Chevrel phase and Prussian blue analogs with easy-made and non-corrosive electrolytes based on $\operatorname{Mg}(\mathrm{TFSI})_{2}$ dissolved in diglyme or acetonitrile. ${ }^{23,24}$ Believing that sulfur-based positive electrodes are the most promising choice to access high energy density Mg batteries, here we prepared a $\mathrm{Mg}_{3} \mathrm{Bi}_{2} / \mathrm{C}$ composite and evaluated it for the first time in a $\mathrm{Mg}$-ion/S battery with a very simple electrolyte formulation.

Figure 1 compares the first cycles of both $\mathrm{Mg} / \mathrm{S}$ and $\mathrm{Mg}_{3} \mathrm{Bi}_{2} / \mathrm{S}$ batteries with $1 \mathrm{M} \mathrm{Mg}(\mathrm{TFSI})_{2} / \mathrm{DME}$ electrolyte, importantly without any added chloride additive and without any prior electrochemical conditioning, evaluated at $\mathrm{C} / 10\left(\sim 160 \mathrm{~mA} / \mathrm{g}\right.$ of sulfur $\left.-\mathrm{g}_{\mathrm{S}}\right)$. $\mathrm{The} \mathrm{Mg}_{3} \mathrm{Bi}_{2} / \mathrm{C}$ composite was prepared 
in few hours by high energy ball-milling and simply blended with conducting carbon and binder to get a sufficiently thick negative electrode. Sulfur-impregnated activated carbon cloth (ACC/S) served as positive electrode (details in supporting information).

a)

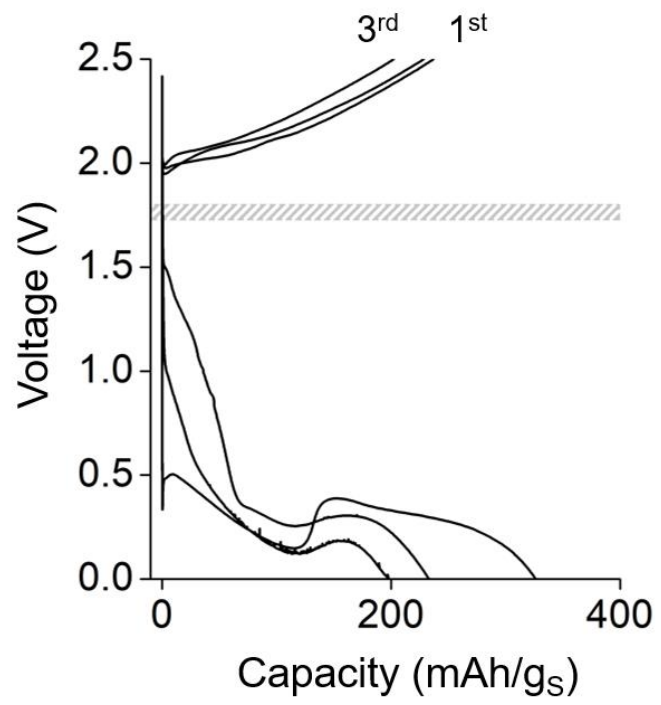

b)

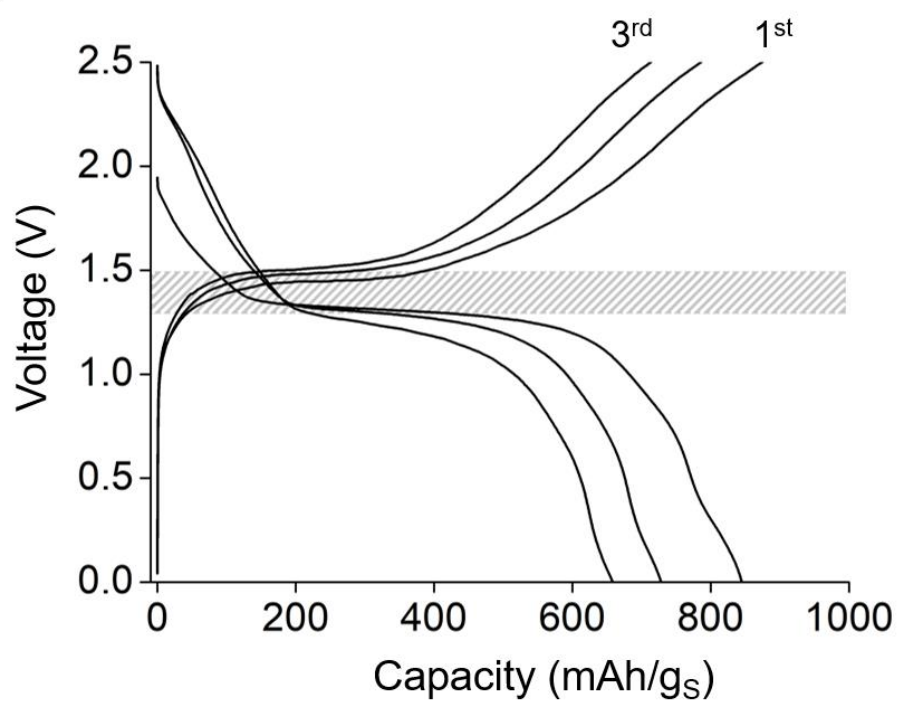

Figure 1: Comparison between first cycles obtained at $\mathrm{C} / 10$ for $\mathrm{Mg} / \mathrm{S}$ cell (a) and $\mathrm{Mg}_{3} \mathrm{Bi}_{2} / \mathrm{S}$ cell (b) with $M g(T F S I)_{2} / D M E$ electrolyte. The grey band represents the theoretical working voltage of each cell and highlights the very high over-potential when $\mathrm{Mg}$ anode is used.

A very large overpotential is observed for the $\mathrm{Mg} / \mathrm{S}$ cell, with a rapid potential drop down below $0.5 \mathrm{~V}$ in discharge. The corresponding capacity is consequently very limited below $400 \mathrm{mAh} / \mathrm{g}_{\mathrm{s}}$. A very high over-potential is also observed in charge, and the shape of the subsequent cycles questions the electrochemical mechanisms that really occur. According to the literature, this over-potential should come from the chemical passivation of the Mg surface occurring as soon as the latter comes in contact with the electrolyte, but could also have an electrochemical origin with the reduction of magnesium polysulfide on the surface. ${ }^{25,26}$ The electrochemical signature strongly differs from that of the $\mathrm{Mg}_{3} \mathrm{Bi}_{2} / \mathrm{S}$ battery. The first discharge starts with a short slope followed by a relatively flat plateau around $1.3 \mathrm{~V}$. A second slope down to $0 \mathrm{~V}$ enables reaching a very high capacity exceeding $800 \mathrm{mAh} / \mathrm{gs}_{\mathrm{s}}$. A similar curve profile is obtained during charge, with a very low 
polarization around $0.3 \mathrm{~V}$. The subsequent cycles demonstrate a quite reversible electrochemical process. The theoretical operation voltage for a $\mathrm{Mg} / \mathrm{S}$ battery cell $(1.7 \mathrm{~V})$ should be decreased by about $0.2-0.3 \mathrm{~V}$ when substituting $\mathrm{Mg}$ by $\mathrm{Mg}_{3} \mathrm{Bi}_{2}$ according to the de-alloying process of the alloy. ${ }^{27}$ The experimental working potentials observed here agree with the theory ( 1.3 and $1.5 \mathrm{~V}$ in discharge and charge, respectively) and underline a very low polarization in spite of the relatively high current density. As similar cathode material and electrolyte formulation were used, the change of cycling profile logically comes from a different behavior at the anode-electrolyte interface. The latter has been further investigated using 3-electrode setup. Comparison between the galvanostatic profiles of $\mathrm{Mg}_{3} \mathrm{Bi}_{2} / \mathrm{S}$ and $\mathrm{Mg} / \mathrm{S}$ cells (Figure S5) highlights the very high polarization of the $\mathrm{Mg}$ anode $(\sim 2 \mathrm{~V})$, whereas the potential gap observed at the $\mathrm{Mg}_{3} \mathrm{Bi}_{2}$ anode is very low $(170 \mathrm{mV})$. Polarization test of a $\mathrm{Mg}_{3} \mathrm{Bi}_{2} / \mathrm{Mg}$ cell confirms the strong passivation that occurs on a Mg electrode (Figure S6). Lastly, EIS has been performed on both $\mathrm{Mg}_{3} \mathrm{Bi}_{2} / \mathrm{S}$ and $\mathrm{Mg} / \mathrm{S}$ cells at $\mathrm{OCV}$ and after the $1^{\text {st }}$ and the $3^{\text {rd }}$ cycle (Figure S7). The impedance of the $\mathrm{Mg}_{3} \mathrm{Bi}_{2}$ anode is maintained below $50 \mathrm{Ohm} \mathrm{cm}^{2}$, whereas for the $\mathrm{Mg}$ anode the already-high OCV impedance increases becoming impossible to measure upon cycling, indicating an extremely strong passivation process. (Fig S7)

Focusing now on the $\mathrm{Mg}_{3} \mathrm{Bi}_{2} / \mathrm{S}$ battery, our early-stage characterizations by operando X-ray diffraction (XRD) confirm the de-alloying process from $\mathrm{Mg}_{3} \mathrm{Bi}_{2}$ to $\mathrm{Bi}$ at the negative side (Figures 2a and S3). Indeed, the formation of Bi is clearly evidenced through the growing peak at $32^{\circ}$, in agreement with the biphasic electrochemical process reported by Murgia et al. ${ }^{27}$ Regarding $\mathrm{Mg}_{3} \mathrm{Bi}_{2}$ peaks, the intensity decreases only slightly because of the large excess of $\mathrm{Mg}_{3} \mathrm{Bi}_{2}$ in the negative electrode with respect to the nominal amount of sulfur on the positive side of the cell. Such a low sulfur loading makes all possible crystalline sulfur species practically invisible by XRD. Conversely, X-ray photoelectron spectroscopy (XPS), allows tracking the evolution of the sulfur species in metal/sulfur battery even at such low loadings. Here, XPS spectra collected ex situ at different battery states shows the conversion of elemental sulfur into polysulfides $\mathrm{MgS}_{\mathrm{x}}$ with a characteristic $S 2 p_{3 / 2}$ at $162 \mathrm{eV}$ (Figure $2 b$ ). ${ }^{7,13,14,16}$ The formation of bridging sulfur is also evidenced during the subsequent charge. However, the detection of sulfur species is biased by the presence of the contributions of $\mathrm{Bi} 4 \mathrm{f}_{7 / 2}$ ad $\mathrm{Bi} 4 \mathrm{f}_{5 / 2}$ peaks at 158.6 and $163.9 \mathrm{eV}$ attributed to a 
slight unexpected $\mathrm{Bi}$ dissolution. It seems reasonable to assume that the $\mathrm{Bi}$ particles generated through the electrochemical de-magnesiation of $\mathrm{Mg}_{3} \mathrm{Bi}_{2}$ have a highly reactive freshly exposed surface, which possibly reacts with sulfur or polysulfide species from the electrolyte, creating bismuth sulfides species which shuttle back to the positive electrode side. Further investigations are actually in progress to confirm or complete this early-stage hypothesis and will be the object of a forthcoming article. Bearing in mind the very simple negative electrode formulation, there is no doubt that a smarter electrode engineering will help circumventing this effect. The sulfite peak ( $\mathrm{S} 2 \mathrm{p} 3 / 2$ at $167.3 \mathrm{eV}$ ) highlights the degradation of the $\mathrm{TFSI}^{-}$anion, as often observed in metal/sulfur batteries.

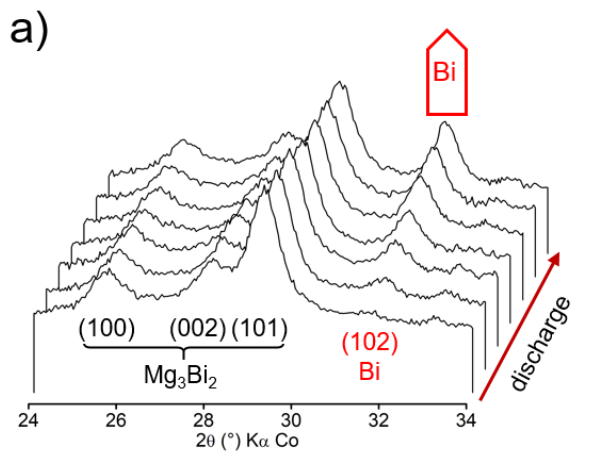

b)

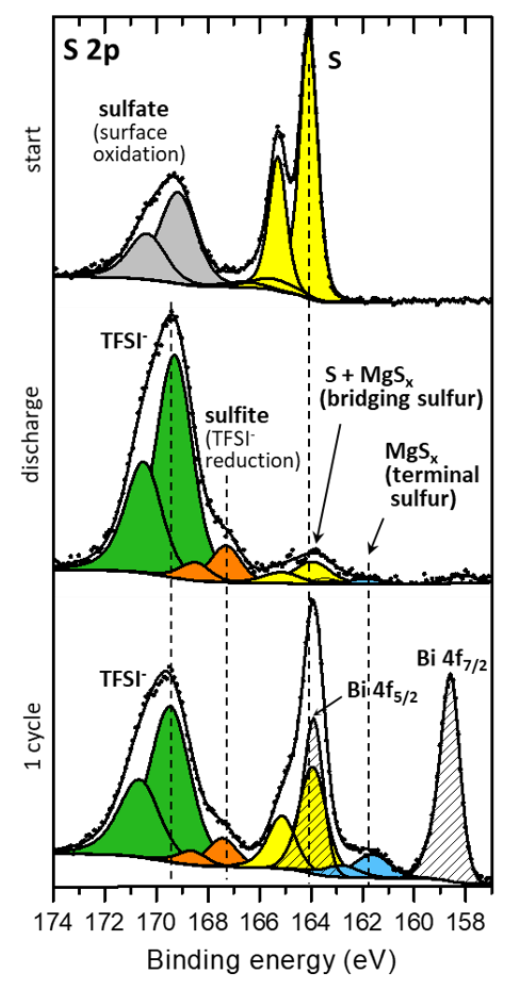


Figure 2: (a) operando XRD monitoring of the negative electrode showing Bi formation during the $\mathrm{Mg}_{3} \mathrm{Bi}_{2} / \mathrm{S}$ battery discharge. The peaks shift in the figure is not real but comes from the waterfall plotting format. (b) ex situ S $2 p$ XPS showing the change of sulfur species at the surface, but also the unexpected presence of Bi species.

The discharge-charge profiles exhibit three distinct regions (slope - plateau-slope), as previously observed with similar ACC/S electrodes and ascribed to the successive formation of $\mathrm{MgS}_{8}, \mathrm{MgS}_{2}$ and lastly solid MgS. ${ }^{14}$ Nevertheless, other profiles have been reported in the literature, with alternative scenarios and different intermediate polysulfide species involved. ${ }^{16,28,29}$ The weak shift of the galvanostatic profiles between each cycle (Fig. S4) certainly accounts for polysulfide species dissolution as commonly reported in all metal/sulfur batteries. Unraveling the detailed mechanism of the electrochemical magnesiation of sulfur in such systems is under investigation but is out of the scope of this Letter.

The promising behavior of $\mathrm{Mg}_{3} \mathrm{Bi}_{2} / \mathrm{S}$ cell obtained at $\mathrm{C} / 10$ is substantiated also by its cycling performance at higher current density. Figure 3 shows the combined evolution of the discharge capacity and the Coulombic efficiency obtained at the high rate of $\mathrm{C} / 2\left(\sim 840 \mathrm{mAh} / \mathrm{g}_{\mathrm{S}}\right)$. The first cycle capacity is considered high as it exceeds $700 \mathrm{mAh} / \mathrm{g}_{\mathrm{S}}$, while its regular decay upon cycling is not surprising if compared to previous works on $\mathrm{Mg} / \mathrm{S}$ battery, and might be ascribed to polysulfide dissolution causing loss of active matter and/or the typical shuttle effect. However, the loss is quite moderate as a capacity of $400 \mathrm{mAh} / \mathrm{g}_{\mathrm{S}}$ is reached after 30 cycles. In order to better evaluate this performance, it was decided to compare it with other pioneering works dealing with similar ACC/S cathodes. Zhao-Karger and coworkers observed similar performance in a Mg/S cell using a $\mathrm{Mg}\left[\mathrm{B}(\mathrm{HFIP})_{4}\right]_{2}$-based electrolyte. However, the cycling rate was limited to $\mathrm{C} / 10$ (167 $\left.\mathrm{mAh} / \mathrm{g}_{\mathrm{S}}\right){ }^{16}$ The group of Wang reported a very stable capacity around $600 \mathrm{mAh} / \mathrm{g}$ at $100 \mathrm{mAh} / \mathrm{g}_{\mathrm{S}}$ for more than 100 cycles. $^{13}$ However, the cell containing a concentrated $1 \mathrm{M}$ $\mathrm{Mg}(\mathrm{TFSI})_{2} / \mathrm{MgCl}_{2} / \mathrm{DME}$ electrolyte which needed to be first conditioned by cyclic voltammetry, and Mo or W current collectors had to be employed to avoid corrosion. There is no doubt that the very low over-potential observed with alloy-type anode participates in these extremely high 
cycling performance. Further investigations are ongoing to evaluate the influence of the simple electrolyte formulation through a systematic benchmarking of other alloy electrodes.

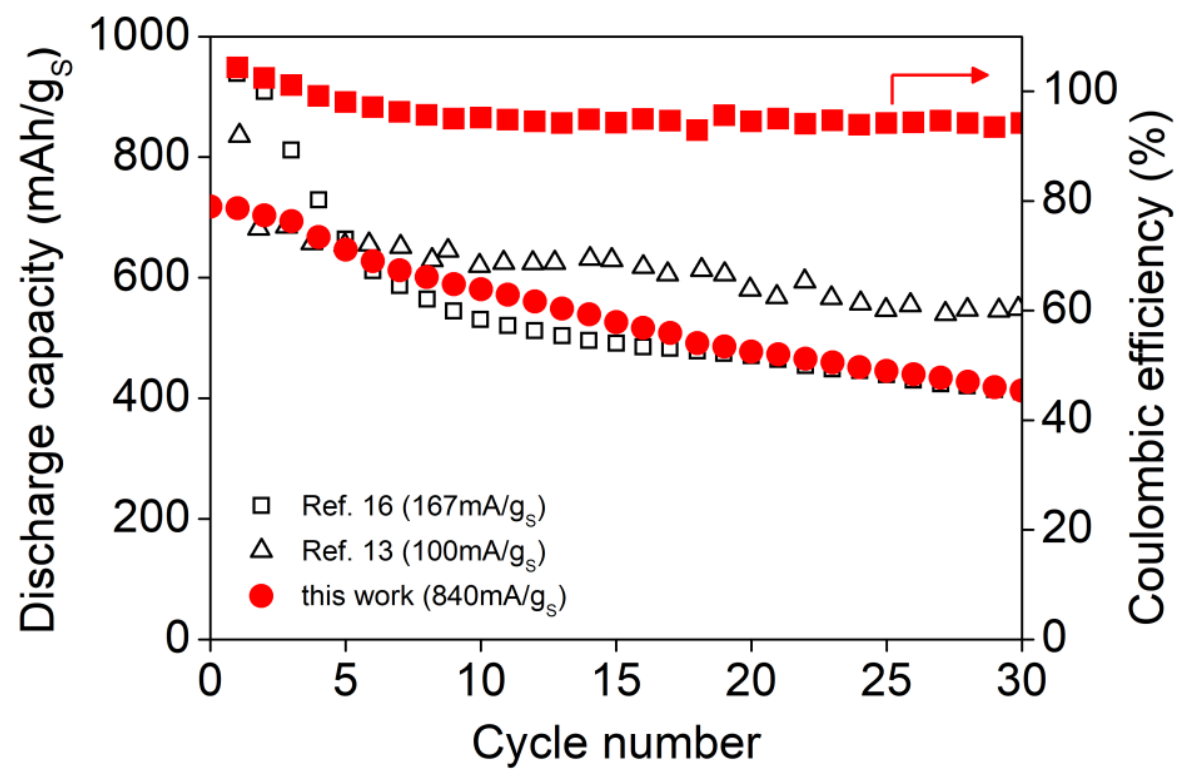

Figure 3: Cycling performance of $\mathrm{Mg}_{3} \mathrm{Bi}_{2} / \mathrm{S}$ coin-cell with $\mathrm{Mg}(\mathrm{TFSI})_{2} / \mathrm{DME}$ electrolyte at $\mathrm{C} / 2$ current rate and comparison with literature using similar ACC/S cathode material. ${ }^{13,16}$

At such an early-stage of the investigation, the cycling performance described above focuses only on the reversible capacity of the sulfur cathode. However, it is important to remind again the average high working potential and the very low polarization increasing the overall energy density of the system. In this regard, it is interesting to simply compare ideal $\mathrm{Mg} / \mathrm{S}$ and $\mathrm{Mg}$-ion/S batteries only using electrode capacities and working potential. Although the effect of the casing is neglected, such calculation still enables one to point out the electrode materials (anode and cathode) that are promising to combine. As shown in Figure 4, replacing Mg by an alloy involves lower energy densities, because of (i) the alloying/de-alloying process that reduces the working potential and (ii) the lower capacities of alloys with respect to Mg. However this comparison needs to be mitigated considering the nominal volume excess of $\mathrm{Mg}$ that must be added in a practical system. The theoretical gap between $\mathrm{Mg}$-ion/S and $\mathrm{Mg} / \mathrm{S}$ reference cells should be significantly decreased, consequently strengthening the interest of using alloy-type anode. 


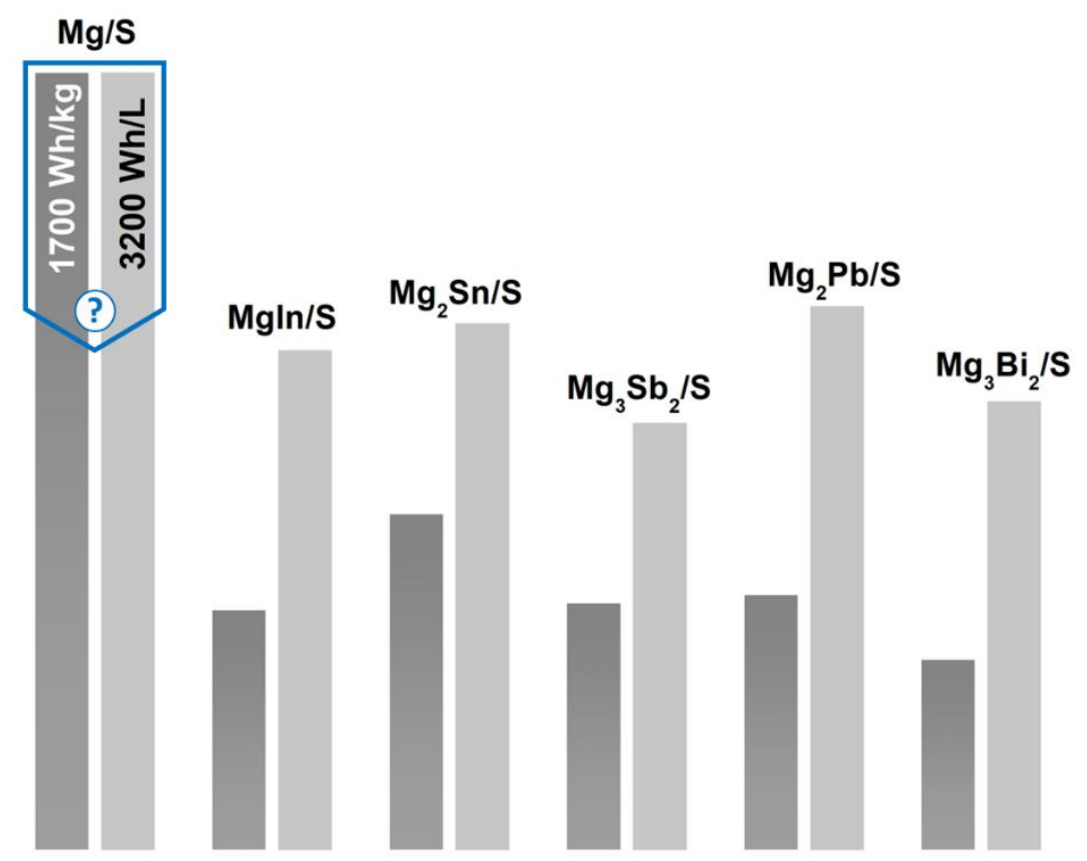

Figure 4: Comparison of theoretical specific or volumetric energy densities between $M g / S$ and various $M g_{x} M / S$ cells. Values are normalized by those for $M g / S$ cell. The down-pointing blue arrow questions the practical decrease that could result from an initial excess of Mg metal at the anode side.

Summarizing, a first proof-of-concept rechargeable Mg-ion/S battery is shown here. The most important point of this concept is the possible use of a simple $\mathrm{Mg}(\mathrm{TFSI})_{2}$-based electrolyte made possible by the replacement of $\mathrm{Mg}$ by $\mathrm{Mg}_{3} \mathrm{Bi}_{2}$. The absence of corrosive chloride species and the unnecessary preliminary conditioning treatment pave the way to a possible industrial transfer. Staying on practical considerations, a good electrode material should also be easily integrated in a suitable electrode formulation. Lamination technology seems adapted to design $\mathrm{Mg}$ thin film but required specific manufacturing conditions. On the contrary, high energy ball milling could easily produce alloy/carbon composite slurries that could then efficiently shaped in electrode by common tape casting. On top of that, the relatively low air-sensitivity of Mg alloys allows one to work in the absence of a controlled atmosphere.

Such early-stage results will be followed by an in-depth investigation of the chemical and electrochemical mechanisms occurring during cycling, with a special effort on probing the anode- 
electrolyte interface to evaluate the chemical reactions between metallic particles and sulfides species and to propose possible strategies to mitigate them.

The very promising cycling performance obtained even at elevated current density might be possibly improved by implementing alternative strategies, for instance by targeting other alloys. Indeed, $\mathrm{Mg}_{3} \mathrm{Bi}_{2}$ was selected in this first work as a model alloy-type negative electrode owing to the particularly good behavior of bismuth in Mg-batteries, but higher theoretical energy densities could be expected using $\mathrm{Mg}_{2} \mathrm{Sn}$ or $\mathrm{Mg}_{2} \mathrm{~Pb}$ anodes (Figure 4). Significant progress can be expected also by playing with the cathode formulation, and especially by targeting higher sulfur loadings. Lastly, such a very simple electrolyte formulation offers room to further optimizations, in particular to tackle the polysulfide shuttle effect and propose battery prototypes with high energy densities and long cycle lives.

\section{Supporting Information}

The Supporting Information section is available free of charge on the ACS Publications website at DOI: $\mathrm{xxx}$.

It includes the preparation and characterization of materials (electrodes and electrolyte), and additional electrochemical analyses performed in 3-electrode cells.

\section{Corresponding author}

* e-mail: romain.berthelot@umontpellier.fr

\section{Notes}

The authors declare no competing financial interest.

\section{Acknowledgments}

The authors thank the French National Research Agency (STORE-EX Labex Project ANR-10LABX-76-01) for financial support. The "Réseau des Rayons X et Gamma" (Univ. Montpellier, France) is gratefully thanked for granting access to their XRD platform. 


\section{References}

1. Aurbach, D. et al. Prototype systems for rechargeable magnesium batteries. Nature 407, 724-727 (2000).

2. Canepa, P. et al. Odyssey of Multivalent Cathode Materials: Open Questions and Future Challenges. Chem. Rev. 117, 4287-4341 (2017).

3. Bucur, C. B., Gregory, T., Oliver, A. G. \& Muldoon, J. Confession of a Magnesium Battery. J. Phys. Chem. Lett. 3578-3591 (2015). doi:10.1021/acs.jpclett.5b01219

4. Muldoon, J., Bucur, C. B. \& Gregory, T. Quest for Nonaqueous Multivalent Secondary Batteries: Magnesium and Beyond. Chem. Rev. 114, 11683-11720 (2014).

5. Yoo, H. D. et al. Mg rechargeable batteries: an on-going challenge. Energy Environ. Sci. 6, 2265-2279 (2013).

6. Zhao-Karger, Z. \& Fichtner, M. Magnesium-Sulfur battery: its beginning and recent progress. MRS Commun. 1-15 (2017).

7. Kim, H. S. et al. Structure and compatibility of a magnesium electrolyte with a sulphur cathode. Nat. Commun. 2, 427 (2011).

8. Zhao-Karger, Z., Zhao, X., Fuhr, O. \& Fichtner, M. Bisamide based non-nucleophilic electrolytes for rechargeable magnesium batteries. RSC Adv. 3, 16330-16335 (2013).

9. Zhao-Karger, Z. et al. Performance Improvement of Magnesium Sulfur Batteries with Modified Non-Nucleophilic Electrolytes. Adv. Energy Mater. 5, 1401155 (2015).

10. Zhao-Karger, Z. et al. Selenium and selenium-sulfur cathode materials for high-energy rechargeable magnesium batteries. J. Power Sources 323, 213-219 (2016).

11. Zhao-Karger, Z. et al. Novel transmetalation reaction for electrolyte synthesis for rechargeable magnesium batteries. RSC Adv. 4, 26924-26927 (2014).

12. Vinayan, B. P. et al. Performance study of magnesium-sulfur battery using a graphene based sulfur composite cathode electrode and a non-nucleophilic Mg electrolyte. Nanoscale 8 , 3296-3306 (2016).

13. Gao, T. et al. Reversible $\mathrm{S} / \mathrm{MgS}_{\mathrm{x}}$ Redox Chemistry in a $\mathrm{MgTFSI}_{2} / \mathrm{MgCl}_{2} / \mathrm{DME}$ Electrolyte for Rechargeable Mg/S Batteries. Angew. Chem. Int. Ed. 129, 13711-13715 (2017).

14. Gao, T. et al. Thermodynamics and Kinetics of Sulfur Cathode during Discharge in $\mathrm{MgTFSI}_{2}$ - DME Electrolyte. Adv. Mater. 1704313 (2017).

15. Zhao-Karger, Z., Gil Bardaji, M. E., Fuhr, O. \& Fichtner, M. A new class of non-corrosive, 
highly efficient electrolytes for rechargeable magnesium batteries. J. Mater. Chem. A 5, 10815-10820 (2017).

16. Zhao-Karger, Z. et al. Toward Highly Reversible Magnesium-Sulfur Batteries with Efficient and Practical Mg[B(hfip) $]_{2}$ Electrolyte. ACS Energy Lett. 3, 2005-2013 (2018).

17. Singh, N., Arthur, T. S., Ling, C., Matsui, M. \& Mizuno, F. A high energy-density tin anode for rechargeable magnesium-ion batteries. Chem. Commun. 49, 149-151 (2013).

18. Arthur, T. S., Singh, N. \& Matsui, M. Electrodeposited Bi, Sb and Bi ${ }_{1-\mathrm{x}} \mathrm{Sb}_{\mathrm{x}}$ alloys as anodes for Mg-ion batteries. Electrochem. Commun. 16, 103-106 (2012).

19. Murgia, F., Weldekidan, E. T., Stievano, L., Monconduit, L. \& Berthelot, R. First investigation of indium-based electrode in $\mathrm{Mg}$ battery. Electrochem. commun. 60, 56-59 (2015).

20. Periyapperuma, K., Tran, T. T., Purcell, M. I. \& Obrovac, M. N. The Reversible Magnesiation of Pb. Electrochim. Acta 165, 162-165 (2015).

21. Darwiche, A. et al. Better cycling performances of bulk $\mathrm{Sb}$ in $\mathrm{Na}$-ion batteries compared to Li-ion systems: an unexpected electrochemical mechanism. J. Am. Chem. Soc. 134, 2080520811 (2012).

22. Sougrati, M. T. et al. TiSnSb a new efficient negative electrode for Li-ion batteries: mechanism investigations by operando-XRD and Mossbauer techniques. J. Mater. Chem. 21, 10069-10076 (2011).

23. Nguyen, D. \& Song, S. Magnesium stannide as a high-capacity anode for magnesium-ion batteries. J. Power Sources 368, 11-17 (2017).

24. Tan, Y.-H. et al. High Voltage Magnesium-ion Battery Enabled by Nanocluster $\mathrm{Mg}_{3} \mathrm{Bi}_{2}$ Alloy Anode in Noncorrosive Electrolyte. ACS Nano 12, 5856-5865 (2018).

25. Tutusaus, O., Mohtadi, R., Singh, N., Arthur, T. S. \& Mizuno, F. Study of Electrochemical Phenomena Observed at the Mg Metal/Electrolyte Interface. ACS Energy Lett. 2, 224-229 (2017).

26. Salama, M. et al. On the Feasibility of Practical Mg-S Batteries: Practical Limitations Associated With Metallic Magnesium Anodes. ACS Appl. Mater. Interfaces 10, 3691036917 (2018).

27. Murgia, F., Stievano, L., Monconduit, L. \& Berthelot, R. Insight into the electrochemical behavior of micrometric $\mathrm{Bi}$ and $\mathrm{Mg}_{3} \mathrm{Bi}_{2}$ as high performance negative electrodes for $\mathrm{Mg}$ 
batteries. J. Mater. Chem. A 3, 16478-16485 (2015).

28. Robba, A. et al. A Mechanistic Study of Magnesium Sulfur Batteries. Chem. Mater. 29, 9555-9564 (2017).

29. Xu, Y. et al. In-situ X-ray absorption spectroscopic investigation of the capacity degradation mechanism in Mg/S batteries. Nano Lett. 19, 2928-2934 (2019). 